variation in a statistical sense. The resolution of the method and limitations in our measured temperature and rock thermal conductivity data restrict the application of the second method to the past few hundred to one thousand years. The paper considers the first approach for the period $1 \mathrm{ka}-10 \mathrm{ka}$ B.P. at about a dozen wells and gives an example of the second approach at a well west of the Agassiz Ice Cap.

Aproach (1). In studying the Devon Island ice core, Fisher and Koerner (1979) present a detailed record of the mean annual air temperature at the site throughout the Holocene, based on the $\delta^{18} \mathrm{O}$ record. A simplified time-temperature model of this record is applied to the ground temperature data set for the period $1 \mathrm{ka}-10 \mathrm{ka}$ B.P. Although the effect on the ground temperatures is only subtly perceptible, the model has the effect of reducing the apparent climatically-related curvature in the data, as reflected in an improvement in the standard deviation in the calculated heat flow profile by $5 \%$ to $30 \%$. Hence, the geothermal record provides quantitative support for Holocene climatic information derived from the ice core record.

Approach (2). This inversion technique is analogous to Paterson's (1968) reconstruction of the surface temperature during the past century from a temperature profile taken in the small Meighen Ice Cap, Arctic Canada. A unique model is not obtained; rather, a small set of possible surface temperature variations consistent with the deeper subsurface temperatures is produced. Such modelling suggests that subsurface temperatures at a well $180 \mathrm{~km}$ west of the Agassiz Ice Cap are consistent with ground surface temperatures some $4-6 \mathrm{~K}$ lower at the well during the Little Ice Age; this is considerably more severe than the mean annual air temperatures projected from the $\delta^{18} \mathrm{O}$ record at Agassiz. It is possible that the large increase in ground surface temperature at the wellsite since the Little Ice Age may be attributed to some climatically-related phenomena such as increased incidence of snow cover coherent with the changing climate. A well on Devon Island is not deep enough for a comparison to that ice cap.

The oxygen isotope data provide a valuable estimate of Holocene climate with which to correct ground temperature data for terrestrial heat flow, or other studies. However, examination of the signal of more recent events suggests that ground temperatures may be considerably modified by associated transient phenomena such as snow cover, vegetation, etc. Hence, one would expect that such a Holocene correction might either understate or overstate the actual experience of the ground surface at a site.

\section{REFERENCES}

Birch, F. 1948. The effects of Pleistocene climatic variations upon geothermal gradients. An. J. Sci., 246, 729-760.

Budd, W.F. and N.W. Young. 1983. Analysis of temperature, isotope and total gas content profiles: application of modelling techniques to measured profiles of temperatures and isotopes. In Robin, G. de Q., ed. The climate record in polar ice sheets. Cambridge, Cambridge University Press, 150-177.

Cermak, V. 1971. Underground temperature and inferred climatic temperature of the past millennium. Palaeogeogr., palaeoclim., palaeoecol., 10, 1-19.

Hotchkiss, W.O. and L.R. Ingersoll. 1934. Postglacial time calculations from recent geothermal measurements in the Calumet copper mines. J. Geol., 42, 113-122.

Jaeger, J.C. 1965. Application of the theory of heat conduction to geothermal measurements. Chapter 2 in Lee, W.H.K., ed. Terrestrial heat flow. (Geophysical monograph series no. 8, American Geophysical Union) 7-23.

Lachenbruch, A.H. and B.V. Marshall. 1986. Changing climate: geothermal evidence from permafrost in the Alaskan Arctic. Science, 234, 689-696.

Lane, A.C. 1923. Geotherms of Lake Superior country. Bull Geol. Soc. Am., 34, 703-720.

Paterson, W.S.B. 1968. A temperature profile through the Meighen Ice Cap, Arctic Canada. IUGG-IASH General Assembly of Bern, Commission of Snow and Ice 1967. (Publ. no. 79 de l'Association Internationale d'Hydrologie Scientifique, Gentbrugge, Belgium), 440-449.

Paterson, W.S.B., and 7 others. 1977. An oxygen-isotope climatic record from the Devon Island ice cap, Arctic Canada. Nature, 266, 508-511.

Vasseur, G., Ph. Bernard, J. Van de Meulebrouck, Y. Kast, and J. Jolivet. 1983. Holocene paleotemperatures deduced from geothermal measurements. Palaeogeogr., palaeoclim., palaeoecol., 43, 237-259.

Weertman, J. 1968. Comparison between measured and theoretical temperature profiles of the Camp Century, Greenland, borehole. J. Geophys. Res., 73, 2691-2700.

\title{
SATELLITE AND OCEANOGRAPHIC OBSERVATIONS OF LARGE ICE-EDGE EDDIES IN THE KURIL BASIN REGION OF THE OKHOTSK SEA
}

\section{(Abstract)}

\author{
by \\ Masaaki Wakatsuchi, \\ (Institute of Low Temperature Science, Hokkaido University, Sapporo 060, Japan)
}

Seelye Martin and Esther Munoz

(School of Oceanography WB-10, University of Washington, Seattle, WA 98195, U.S.A.)

We examined the behavior of the sea ice in the Okhotsk Sea which formed over the deep Kuril Basin during the period 1978-82. When ice extended over the basin, we observed the formation of large eddies with diameters of order $200 \mathrm{~km}$. We determined the size and duration of these eddies through use of the $37 \mathrm{GHz}$ channel on the Nimbus 7 Scanning Multichannel Microwave Radiometer, and with the visible channel on the geostationary Himawari satellite. Within the ice cover, the satellite data show that these eddies produced open-water regions which persisted for $4-6$ weeks, and that the eddies recurred year after year, even though their relative position changed. Comparison of eddy positions determined from satellite data with oceanographic positions shows that the oceanography drives the eddies. An estimate of heat loss from these eddies shows that the role of the ocean eddies is to keep the region ice-free until heat loss approaches zero, so that fluxes over the eddies primarily cool the water column without adding salt. Then as the atmosphere begins to warm in spring, the eddies tend to become ice-covered, so that melt water is introduced to their surface. Examination of the oceanography shows that the early 
summer water-column structure depends on the heat loss from the region during the preceding ice season, the amount of ice over the basin, and the total amount of ice formation in the Okhotsk Sea. During the heavy ice year of 1979 , the upper $200-300 \mathrm{~m}$ were cooler, less saline, and highly oxygenated. This modification appears to be a local process, driven by eddy-induced mixing, local cooling, and ice melting. At $300-1200 \mathrm{~m}$ depths, water modification is caused by advection of water from outside the Kuril Basin. During heavy ice years with strong cooling, this water is more saline, colder, and richer in oxygen than during lighter ice years. The water modified in the basin can be traced into the North Pacific, where it cools and dilutes the surface water, and oxygenates the upper $200-400 \mathrm{~m}$.

\title{
INCREASED ACCUMULATION ON THE ANTARCTIC ICE SHEET DUE TO CLIMATIC WARMING
}

\author{
(Abstract)
}

by

Stephen Warren*

(Glaciology Section, Antarctic Division, Earth Sciences School, University of Melbourne, Parkville, Victoria 3052, Australia)

and

Susan Frankenstein

(Oceanography Department, University of Washington, Seattle, WA 98195, U.S.A.)

Climatic warming due to increased greenhouse gases is expected to cause increased precipitation in the next century because of the increased water content of the air, assuming constant relative humidity. Since temperatures over most of Antarctica are far below freezing even in the warmest month of the year, the increase in melting is probably negligible compared to the increase in precipitation.

Oerlemans (1982) showed that this increase of precipitation would cause a growth of the ice sheet, tending to lower sea level. This would partially counteract the rise of sea level due to increased melting on mountain glaciers and Greenland, and to a possible (and more difficult to predict) surge of ice from West Antarctica.

Oerlemans may have underestimated the increase in accumulation. He used results of General Circulation Models (GCMs) which indicated an increase of precipitation by only $12 \%$ for a temperature change $\Delta \mathrm{T}=3 \mathrm{~K}$ and $30 \%$ for $\Delta \mathrm{T}=$ $8 \mathrm{~K}$. In contrast, the change in accumulation rate at Dome C (Lorius and others, 1979) accompanying the warming from the recent ice age to the present was in accord with the simple assumption that accumulation is proportional to saturation vapor pressure at the temperature of the inversion layer, i.e. a $30 \%$ increase for $\Delta \mathrm{T}=3 \mathrm{~K}$.

The experimental results are to be preferred to the climate model results because GCMs do not represent icesheet accumulation processes well. Most of the accumulation is not snow falling from clouds but instead results from clear-sky ice-crystal formation in near-surface air, or hoarfrost deposition on the surface. GCMs lack sufficient vertical resolution to represent the strong temperature inversion on which these accumulation mechanisms depend.

The figure shows that the increase of vapor pressure due to $\Delta \mathrm{T}=5 \mathrm{~K}$ varies from a factor of 1.9 at $\mathrm{T}=-60^{\circ} \mathrm{C}$ to a factor of 1.6 at $\mathrm{T}=-20^{\circ} \mathrm{C}$. A climatic warming of $5 \mathrm{~K}$ over Antarctica, which is possible during the next century, could thus increase the Antarctic accumulation from its present $17 \mathrm{~g} \mathrm{~cm}^{-2} \mathrm{yr}^{-1}$ to $30 \mathrm{~g} \mathrm{~cm}^{-2} \mathrm{yr}^{-1}$, leading to a

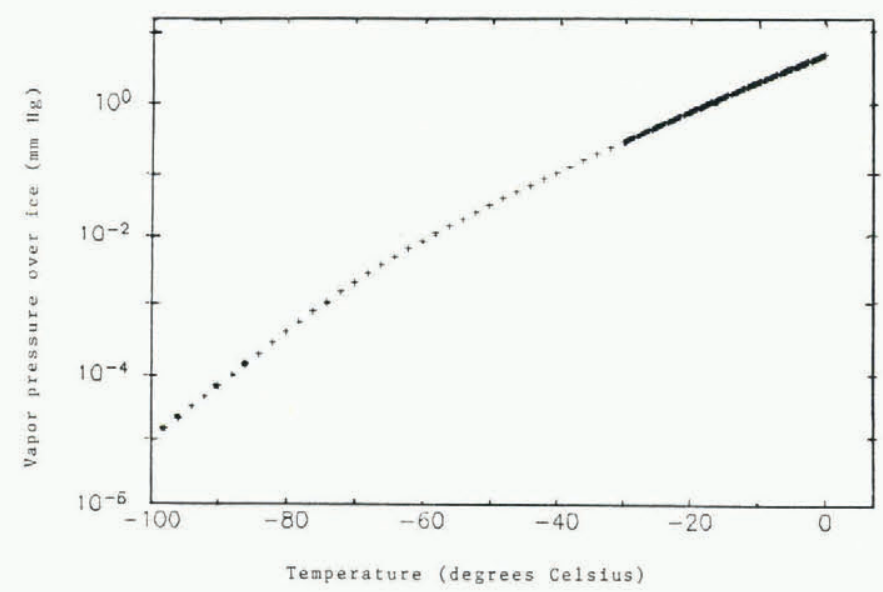

$50 \mathrm{~cm}$ drop in sea level in 100 years. This assumes that the simple proportionality of precipitation rate to saturation vapor pressure applies as well to the coastal regions, which is doubtful because the accumulation processes are not the same as on the plateau.

The potential importance of Antarctic accumulation changes in contributing to changes of sea level argues for further study of the mechanisms of Antarctic precipitation and for their improved representation in climate models.

\section{REFERENCES}

Lorius, C., L. Merlivat, J. Jouzel, and M. Pourchet. 1979. A $30000-y r$ isotope climatic record from Antarctic ice. Nature, 280, 644-648.

Oerlemans, J. 1982. Response of the Antarctic ice sheet to a climatic warming: a model study. J. Climatol., 2, 1-11.

* current address: Atmospheric Sciences, AK40, University of Washington, Seattle, WA 98195, U.S.A. 